\title{
Nongenomic effect of thyroid hormone on free-radical production in human polymorphonuclear leukocytes
}

\author{
E Mezosi, J Szabo, E V Nagy, A Borbely', E Varga, G Paragh and \\ Z Varga
}

Divisions of Endocrinology and Metabolism, First Department of Medicine, University of Debrecen, Hungary

${ }^{1}$ Department of Microbiology, Medical and Health Science Centre, University of Debrecen, Hungary

(Requests for offprints should be addressed to Z Varga; Email: vargazs@ibel.dote.hu)

\begin{abstract}
Over the past few years increasing evidence has suggested the nongenomic effects of thyroid hormone, such as the activation of the signal transduction pathways and the activation of nuclear factor- $\mathrm{\kappa B}$ by the induction of oxidative stress. The present study was undertaken to investigate the effect of thyroid hormone on human polymorphonuclear leukocytes (PMNLs) which are known as important sources of reactive oxygen species in the circulation. The production of superoxide anion $\left(\mathrm{O}_{2}{ }^{-}\right)$and the activity of myeloperoxidase were determined in the presence and absence of several inhibitors of the signalling pathway. L-Thyroxine $\left(\mathrm{T}_{4}\right)$, L-3,5,3'-tri-iodothyronine $\left(\mathrm{T}_{3}\right)$ and L-3,5-di-iodothyronine $\left(\mathrm{T}_{2}\right)$ stimulated $\mathrm{O}_{2}{ }^{-}$production in PMNLs in a dose-dependent manner within a few minutes of addition to cells. Thyroid hormone-stimulated $\mathrm{O}_{2}{ }^{-}$production was partially inhibited by pertussis toxin, an inhibitor of GTP-binding G protein, and was completely abolished by the protein kinase $\mathrm{C}$ inhibitors
\end{abstract}

calphostin C and Ro-32-0432, and by a calcium chelator (BAPTA; bis-(o-aminophenoxy)ethane- $N, N, N^{\prime}, N^{\prime}$-tetraacetic acid). Thyroid hormone stimulated myeloperoxidase activity and induced ${ }^{125} \mathrm{I}^{-}$incorporation into PMNLs. Furthermore, thyroid hormone pre-incubation enhanced $\mathrm{O}_{2}{ }^{-}$production for $n$-formyl-methionyl-leucylphenylalanine (FMLP) stimulation. In conclusion, novel nongenomic actions of thyroid hormone, the induction of superoxide anion production and the stimulation of myeloperoxidase activity in PMNLs were demonstrated. The induction of $\mathrm{O}_{2}{ }^{-}$production requires calcium and is mediated by a pertussis toxin-sensitive $G$ protein via stimulation of protein kinase $\mathrm{C}(\mathrm{s})$. These results suggest the existence of a membrane-bound binding site for thyroid hormone in PMNLs and a physiological role for thyroid hormone in the cellular defence mechanisms by stimulating free-radical production.

Journal of Endocrinology (2005) 185, 121-129

\section{Introduction}

Most effects of thyroid hormone are mediated by a direct modulation of gene activity via interaction of the thyroid hormone-nuclear receptor complex with specific DNA sequences (Ojamaa et al. 1996). Several results have showed that cellular uptake of thyroid hormone is mediated by carrier proteins and/or binding sites in various cells (Hennemann et al. 2001).

Actions of thyroid hormone that are independent of intranuclear ligand binding of hormone by nuclear thyroid hormone receptors are called nongenomic (Davis \& Davis 1996). Over the past few years increasing evidence has been raised which suggests several nongenomic effects of thyroid hormone (Davis \& Davis 1996, 2002), such as the stimulation of plasma membrane transport (Huang et al. 1999, Incerpi et al. 1999), the modulation of enzyme activities (adenylate cyclase, $\mathrm{Ca}^{2+}$-ATPase; Davis et al. 1989, Sakaguchi et al. 1996), the regulation of mitochon- drial processes (Goglia et al. 1999), acute changes in the electrical properties of the cell membrane (Ribeiro et al. 1998, Sundquist et al. 1992), the activation of signal transduction pathways (Lanni et al. 1994, Szabo et al. 1996, Lin et al. 1999a) and the activation of nuclear factor- $\mathrm{KB}$ by the induction of oxidative stress (Tapia et al. 2003).

Nongenomic effects of thyroid hormone are distinguished from the nucleus-mediated actions by the structure-activity relationships and by the onset of actions (Davis \& Davis 1996). Genomic actions are exerted by L-3,5, $3^{\prime}$-tri-iodothyronine $\left(\mathrm{T}_{3}\right)$ while L-thyroxine $\left(\mathrm{T}_{4}\right)$, reverse $\mathrm{T}_{3}\left(\mathrm{rT}_{3}\right)$ or $\mathrm{L}-3,5$-di-iodothyronine $\left(\mathrm{T}_{2}\right)$ have predominantly nongenomic activity (Davis \& Davis 1996). Specific binding sites for $T_{3}$ have been identified in highly purified membrane preparations of various cell types such as liver cells, neuroblasts and pituitary cells (Segal 1990, Chapell et al. 1998, Davis \& Davis 2002, Harvey \& Williams 2002). However, the structure of the cell-surface receptor for thyroid hormone is unknown. 
The physiological significance and molecular mechanisms of most nongenomic actions are incompletely understood. Recently, extranuclear actions of steroid hormone have also been recognized, and many similarities in the nongenomic effect of the steroids and thyroid hormone have been demonstrated (Davis et al. 2002).

Many years ago, increased metabolic activities in polymorphonuclear leukocytes (PMNLs) of hyperthyroid patients were described (Balazs et al. 1980). Alterations in the respiratory burst and arachidonic acid metabolism in PMNLs of patients with thyroid disorders have also been demonstrated (Videla et al. 1993, Szabo et al. 1996, Magsino et al. 2000). Based on these data, one can assume that thyroid hormone exerts a modulating effect in human PMNLs. Therefore, the aim of the present study was to investigate the effect of thyroid hormones $\left(\mathrm{T}_{2}, \mathrm{~T}_{3}\right.$ and $\mathrm{T}_{4}$ ) on human PMNLs and to evaluate the potential mechanisms of these actions. The possible physiological role of thyroid hormone was investigated by measuring $\mathrm{O}_{2}{ }^{-}$release, myeloperoxidase activity and incorporation of ${ }^{125} \mathrm{I}^{-}$into PMNLs of healthy subjects. Basic and n-formyl-methionyl-leucyl-phenylalanine (FMLP)-induced $\mathrm{O}_{2}{ }^{-}$production in PMNLs of hyper- and hypothyroid patients was also determined.

Here we show that the rapid nongenomic effects of thyroid hormone in PMNLs are the stimulation of superoxide anion production via the activation of the protein kinase $\mathrm{C}(\mathrm{PKC})$ pathway, the induction of ${ }^{125} \mathrm{I}^{-}$ incorporation and the enhancement of myeloperoxidase activity.

\section{Materials and Methods}

\section{Patients}

20 female patients were included in the study. The diagnosis was confirmed by evaluating the clinical data and by measurement of free $T_{4}$, free $T_{3}$, sensitive thyroidstimulating hormone (sTSH), and anti-thyroid peroxidase and anti-TSH receptor antibodies. 12 recently diagnosed, untreated patients suffering from Graves' disease were hyperthyroid (mean age, $53 \pm 15$ years). The mean free $\mathrm{T}_{4}$ was $51.36 \mathrm{pM}$ (normal range, $7 \cdot 2-23.3 \mathrm{pM}$ ). Eight patients suffered from hypothyroidism of various origins: two patients after thyroid surgery, four Graves' patients following radioiodine treatment and two patients with Hashimoto thyroiditis (mean age, $51 \pm 9$ years). The mean sTSH was 39.57 IU/1 (normal range, 0.3-3 IU/1). 15 ageand sex-matched healthy volunteers served as controls. All patients and controls gave their informed consent, which conformed to the rules of the Ethical Committee of the University of Debrecen.

\section{Materials}

Cytochrome $c$, superoxide dismutase, FMLP, $\mathrm{T}_{2}, \mathrm{~T}_{3}, \mathrm{~T}_{4}$, pertussis toxin, staurosporine, Histopaque 1077, Hanks' balanced salt solution (HBSS), propylthiouracil (PTU), RPMI 1640, phorbol myristate acetate (PMA), o-dianiside and $\mathrm{H}_{2} \mathrm{O}_{2}$ were purchased from Sigma (St Louis, MO, USA). ${ }^{125} \mathrm{I}^{-}$as its sodium salt solution $(15 \mathrm{GBq} / \mathrm{ml})$ was from Izinta (Budapest, Hungary). Calphostin $\mathrm{C}$ and Ro-32-04432 were from Calbiochem (CN Bioscience Company, Darmstadt, Germany).

\section{Preparation of thyroid hormone solution}

Thyroid hormone $\left(\mathrm{T}_{2}, \mathrm{~T}_{3}\right.$ and $\left.\mathrm{T}_{4}\right)$ was dissolved in $\mathrm{NaOH}$ $(0 \cdot 3 \mathrm{M}) ; 10^{-3} \mathrm{M}$ stock solution was prepared. The stock solution was diluted immediately with HBSS to achieve the appropriate concentrations. The same amount of diluted $\mathrm{NaOH}$ solution was added to the control cells as to the thyroid hormone-treated cells. The diluted solution did not affect $\mathrm{O}_{2}{ }^{-}$production in PMNLs.

\section{Isolation of PMNLs}

After obtaining informed consent, PMNLs were isolated from blood of fasting healthy volunteers and fasting thyroid patients. Cells were separated by density centrifugation using Histopaque 1077 according to the method of Boyum (Boyum 1968). Contaminating erythrocytes were removed by hypotonic lysis and cells were suspended in HBSS at a cell density of $1 \times 10^{6}$ cells $/ \mathrm{ml}$. PMNLs were at least 95\% viable, as judged by Trypan Blue exclusion test.

$\mathrm{O}_{2}{ }^{-}$release

$\mathrm{O}_{2}{ }^{-}$release was determined in HBSS by measuring the reduction of cytochrome $c$ at $\lambda=550 \mathrm{~nm}$ using a micro assay as published previously in detail (Czompa et al. 2000). Superoxide dismutase was also added to the samples to check that reduction of cytochrome $c$ was due to formation of $\mathrm{O}_{2}{ }^{-} \cdot \mathrm{T}_{2}, \mathrm{~T}_{3}$ and $\mathrm{T}_{4}$ were used in a concentration range of $10^{-4}-10^{-9} \mathrm{M}$, FMLP at $10^{-8} \mathrm{M}$ and PMA at $10^{-7} \mathrm{M}$. Pertussis toxin, an inhibitor of GTP-binding G protein, was used at a concentration of $100 \mathrm{ng} / \mathrm{ml}$. Cells were incubated with pertussis toxin for $2 \mathrm{~h}$ at $37^{\circ} \mathrm{C}$ in RPMI 1640. Staurosporine, a non-specific inhibitor of protein kinases, was used at a concentration of $100 \mathrm{nM}$ and was added to cells 2 min prior to stimulation. Calphostin C, a cell-permeable, highly specific inhibitor of PKC(s), was used at $50 \mathrm{nM}$, Ro-32-0432, a selective inhibitor of $\mathrm{PKC} \alpha$ and $\mathrm{PKC} \beta \mathrm{I}$, was used in a range of 1-10 nM, and BAPTA (bis-(o-aminophenoxy)ethane$N, N, N^{\prime}, N^{\prime}$-tetra-acetic acid), a calcium chelator, was used at $10^{-5} \mathrm{M}$ concentration. In all cases the pre-incubation time was $10 \mathrm{~min}$. When the effect of thyroid hormone pre-treatment on FMLP-induced $\mathrm{O}_{2}{ }^{-}$release was studied, PMNLs were pre-incubated with $\mathrm{T}_{2}, \mathrm{~T}_{3}$, and $\mathrm{T}_{4}$ for 5 min prior to stimulation with FMLP. Reduction in cytochrome $c$ was recorded prior to stimulation $\left(T=T_{0}\right)$ and at the times indicated on the figures. Results were 
calculated by the equation: Absorbency $=\left(T-T_{0}\right)$ / $(\varepsilon \times N \times 1)$, where $\varepsilon$ is the molar extinction coefficient of cytochrome $c\left(2 \cdot 1 \times 10^{-2} \mu \mathrm{mol}^{-1}\right), N$ is the cell number and 1 is light passlength $(\mathrm{cm})$. All experiments were performed in triplicate.

\section{Effect of PTU on $\mathrm{O}_{2}{ }^{-}$release in PMLNs}

Human PMNLs were preincubated with PTU at a concentration range of $50-1000 \mu \mathrm{M}$ for $10 \mathrm{~min}$ prior to stimulation with thyroid hormone, FMLP or PMA. The latter stimulators were used to control the general effect of PTU, if any, on $\mathrm{O}_{2}{ }^{-}$production in PMNLs.

${ }^{125} \mathrm{I}^{-}$incorporation into PMNLs was determined in the presence and absence of $\mathrm{T}_{3}$ and $\mathrm{T}_{4}$. PMNLs $\left(5 \times 10^{6}\right.$ cells $/ \mathrm{ml}$ ) were incubated with $15 \mu \mathrm{Ci}^{125} \mathrm{I}^{-}$in the presence and absence of $T_{3}$ and $T_{4}\left(10^{-6}-10^{-7} \mathrm{M}\right)$ for $30 \mathrm{~min} .{ }^{125} \mathrm{I}$ was added as its sodium salt solution to HBSS at the same time thyroid hormone was added. The reaction was stopped by the addition of ice-cold HBSS. Cells were washed three times with ice-cold HBSS and the incorporated ${ }^{125} \mathrm{I}^{-}$activity was determined in cell pellets by Gamma NK 350 counter.

Myeloperoxidase activity was determined, as described previously (Mohacsi et al. 1996). Namely, PMNLs $\left(1 \times 10^{6}\right.$ cells $\left./ \mathrm{ml}\right)$ were incubated in HBSS in the presence of thyroid hormone $\left(T_{2}, T_{3}\right.$ or $\left.T_{4}\right)$ for $60 \mathrm{~min}$. Cells were centrifuged $\left(400 \mathrm{~g}, 10 \mathrm{~min}\right.$ at $\left.4{ }^{\circ} \mathrm{C}\right)$ after the incubation and supernatants of cells were assayed for myeloperoxidase activity in citrate buffer, $\mathrm{pH} 5.5$, containing $0.32 \mathrm{mM}$ $o$-dianiside and $0.08 \mathrm{mM} \mathrm{H}_{2} \mathrm{O}_{2}$. The reaction was started by the addition of the sample and was stopped after $1 \mathrm{~min}$ with $1 \mathrm{ml} \mathrm{35 \%}$ perchloric acid. The absorbance of the samples was read at $560 \mathrm{~nm}$ in a Hewlett Packard spectrophotometer. The enzyme activity was expressed as $\mathrm{nmol}$ product/min per $1 \times 10^{6}$ cells using an extinction coefficient of $2 \times 10^{4} \mathrm{M}^{-1} \mathrm{~cm}^{-1}$ at $560 \mathrm{~nm}$. All measurements were performed in triplicate.

Statistical analysis was performed using ANOVA and paired Student's $t$-test and differences were considered significant if $P<0 \cdot 05$. Data are expressed as mean \pm S.D. from three independent experiments. All experiments were performed in triplicate.

\section{Results}

All of the studied thyroid hormone analogues (Fig. 1), $\mathrm{T}_{2}$, $\mathrm{T}_{3}$ and $\mathrm{T}_{4}$, enhanced the $\mathrm{O}_{2}{ }^{-}$release in PMNLs in a concentration-dependent manner. The highest stimulation was observed when thyroid hormones were used at $10^{-7}-10^{-9} \mathrm{M}$ (Fig. 1).

The kinetics of thyroid hormone-induced $\mathrm{O}_{2}{ }^{-}$release (Fig. 2) were compared with the time-dependent effect of FMLP, which is a well-known stimulator of respiratory burst in human PMNLs (Fig. 2). An increase in $\mathrm{O}_{2}{ }^{-}$

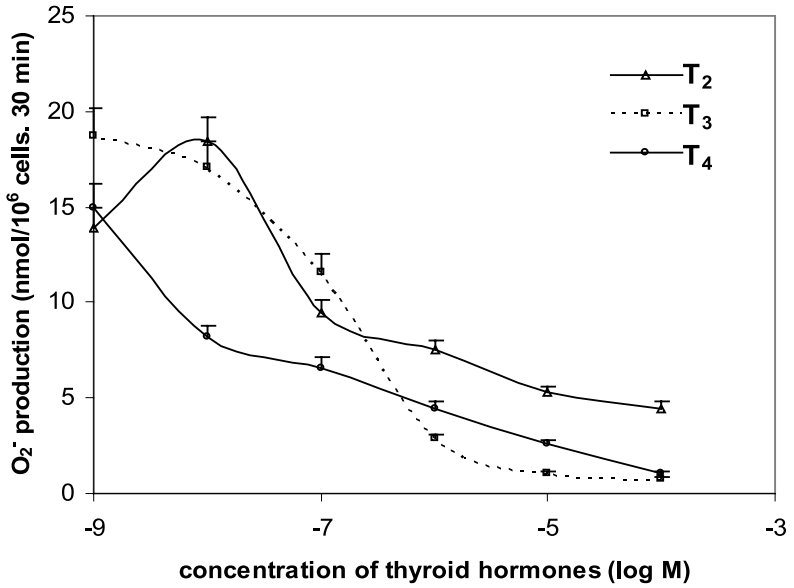

Figure 1 Thyroid hormone $\left(T_{2}, T_{3}\right.$ and $\left.T_{4}\right)$ induced superoxide anion production in a concentration-dependent manner in PMNLs of healthy subjects. Results represent means \pm s.D. from three independent experiments. All experiments were performed in triplicate. Significance for all three hormones at $10^{-8} \mathrm{M}$ versus resting cells was $P<0 \cdot 001$.

production was observed after 3-7 min of incubation with thyroid hormone analogues, and a nearly linear rise in $\mathrm{O}_{2}{ }^{-}$formation was detected during 20 min of incubation. The pre-incubation of PMNLs with thyroid hormone prior to stimulation with FMLP resulted in an additive effect in terms of $\mathrm{O}_{2}{ }^{-}$production (Fig. 2).

In order to clarify the potential mechanism of thyroid hormone action, PMNLs were treated with several inhibitors of the signal transduction mechanisms (Figs 3 and 4). Effects of inhibitors on thyroid hormone-induced $\mathrm{O}_{2}{ }^{-}$ release were compared with their effects on FMLP signalling. FMLP is the best-characterized activator of NADPH oxidase in neutrophils. It functions via a $G$ protein-linked chemotactic peptide receptor, increases cytosolic free calcium concentration, and activates phospholipase $\mathrm{C}$ and PKC. Classical PKC isoenzymes are involved in the signal transduction of FMLP (Chen \& Jan 2001). The $\mathrm{O}_{2}{ }^{-}$ release of PMNLs induced by $T_{2}, T_{3}$ and $T_{4}$ or FMLP was partially inhibited by pertussis toxin, an inhibitor of GTP-binding G proteins (Fig. 3). Staurosporine, a nonspecific protein kinase inhibitor, entirely blocked $\mathrm{O}_{2}{ }^{-}$ production induced by thyroid hormone analogues and FMLP (Fig. 3). Calphostin C, a general inhibitor of PKCs, which interacts with the regulatory domain of PKC by competing at the binding site of diacylglycerol and phorbol esters, and Ro-32-0432, a highly specific inhibitor of classical PKC isoenzymes (with $\mathrm{IC}_{50}=9 \mathrm{nM}$ for $\mathrm{PKC} \alpha$ and $\mathrm{IC}_{50}=28 \mathrm{nM}$ for $\mathrm{PKC} \beta \mathrm{I}$ ), abolished the thyroid hormoneand FMLP-induced $\mathrm{O}_{2}{ }^{-}$release to similar extents (Fig. 4). The inhibitory effect of Ro-32-0432 was significant at a very low concentration ( $1 \mathrm{nM}$; data not shown) and remained so when used at $10 \mathrm{nM}$ (Fig. 4). Calcium chelator BAPTA also inhibited $\mathrm{O}_{2}{ }^{-}$release induced by 

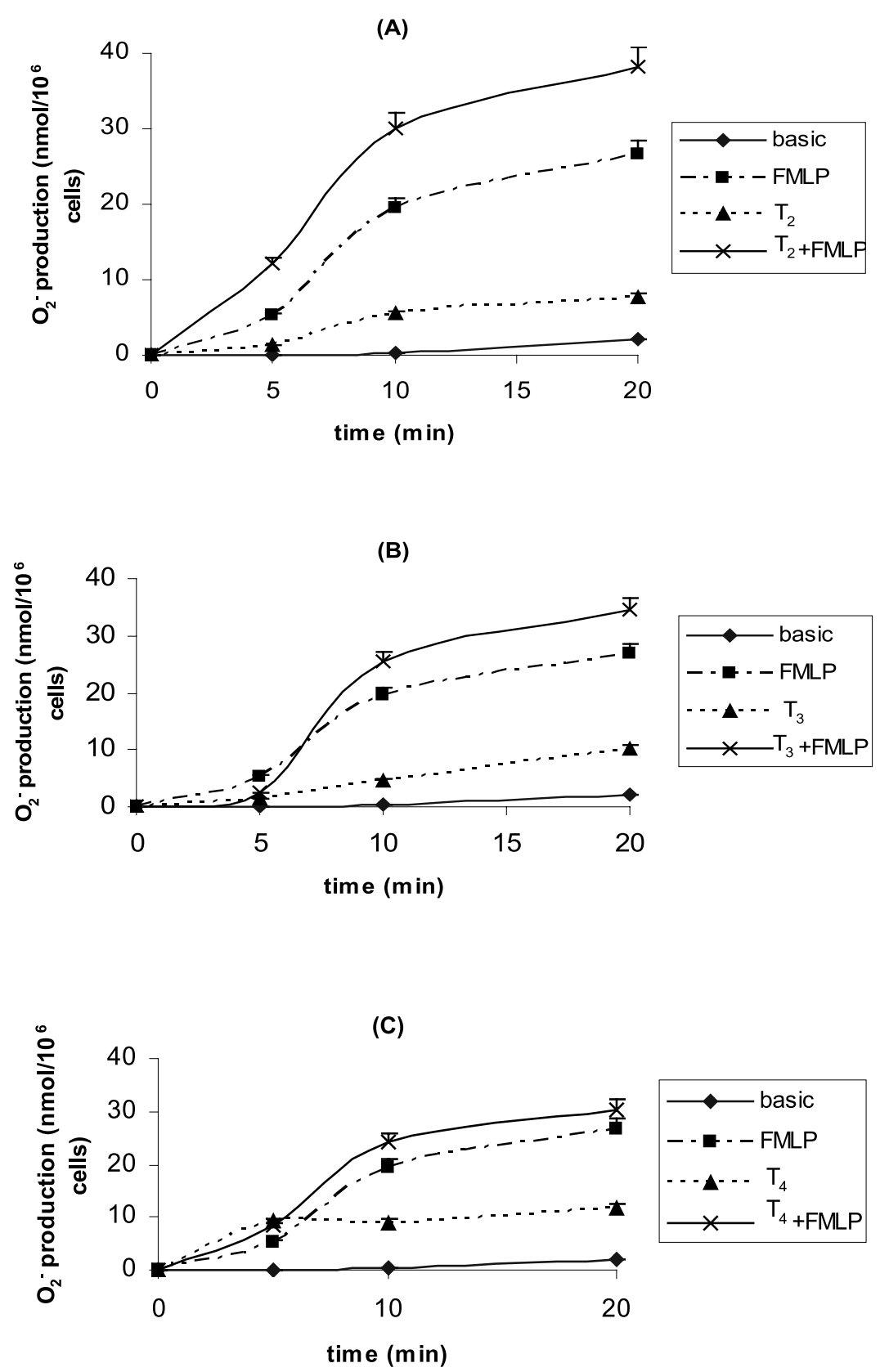

Figure 2 Time-dependent $\mathrm{O}_{2}{ }^{-}$release in PMNLs of healthy subjects in the presence of thyroid hormone alone, FMLP alone, and thyroid hormone and FMLP added together. (A) Effect of $\mathrm{T}_{2} ;(\mathrm{B})$ effect of $\mathrm{T}_{3} ;(\mathrm{C})$ effect of $\mathrm{T}_{4}$. PMNLs were pre-incubated with thyroid hormone $\left(10^{-8} \mathrm{M}\right)$ for 5 min prior to stimulation with FMLP $\left(10^{-8} \mathrm{M}\right)$. Results represent means \pm S.D. from three independent experiments. All experiments were performed in triplicate. Significance levels for all three hormones alone and added together with FMLP versus resting cells and FMLP-stimulated cells were $P<0.001$ and $P<0 \cdot 01$, respectively.

thyroid hormone and FMLP to similar extents (Fig. 4). It should be noted that specific PKC inhibitors (Ro-320432 and calphostin C) and the calcium chelator
(BAPTA) inhibited thyroid hormone-induced $\mathrm{O}_{2}{ }^{-}$production in PMLNs at all concentrations $\left(10^{-6}-10^{-9} \mathrm{M}\right)$ tested (data not shown). 


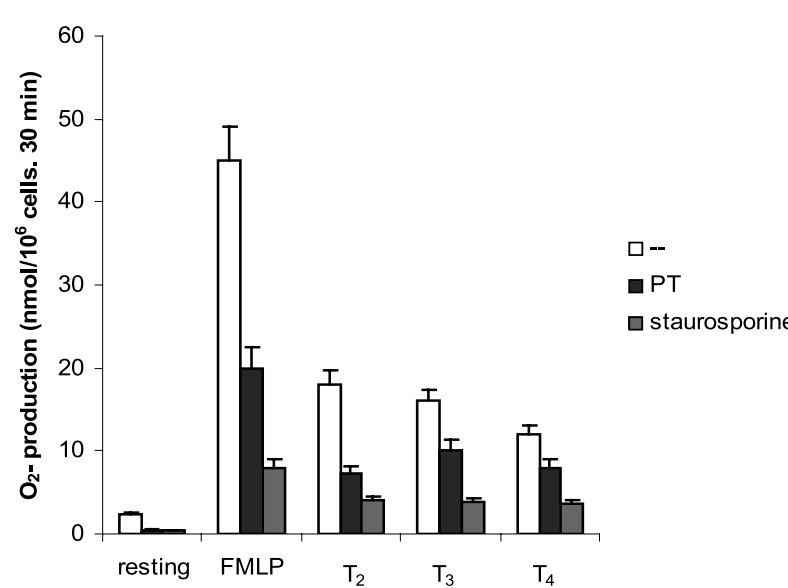

Figure 3 The effect of pertussis toxin (PT) and staurosporine on thyroid hormone- and FMLP-induced $\mathrm{O}_{2}{ }^{-}$generation in PMNLs. $\mathrm{T}_{2}, \mathrm{~T}_{3}$ and $\mathrm{T}_{4}$ and FMLP were used at $10^{-8} \mathrm{M}$. The cells were incubated for $2 \mathrm{~h}$ with $100 \mathrm{ng} / \mathrm{ml}$ pertussis toxin prior to stimulation. Staurosporine was added to cells 2 min prior to stimulation, at $100 \mathrm{nM}$. Values are expressed as means \pm S.D. from three independent experiments. The inhibitory effect of pertussis toxin and staurosporine proved to be significant in all cases $(P<0 \cdot 02)$.

Theoretically it is possible that $\mathrm{T}_{2}$ is the only thyroid hormone responsible for the observed $\mathrm{O}_{2}{ }^{-}$production in PMNLs. $T_{4}$ and $T_{3}$ may be converted to $T_{3}$ and $T_{2}$ by peripheral deiodination in granulocytes. In order to investigate this opportunity, the effect of PTU, an inhibitor of peripheral deiodination, was also studied (Fig. 5). It was found that PTU at its therapeutic concentration $(50 \mu \mathrm{M})$ decreased $\mathrm{O}_{2}{ }^{-}$production in PMNLs after all thyroid hormone $\left(\mathrm{T}_{2}, \mathrm{~T}_{3}\right.$ and $\mathrm{T}_{4}$ ), and FMLP (but not PMA)

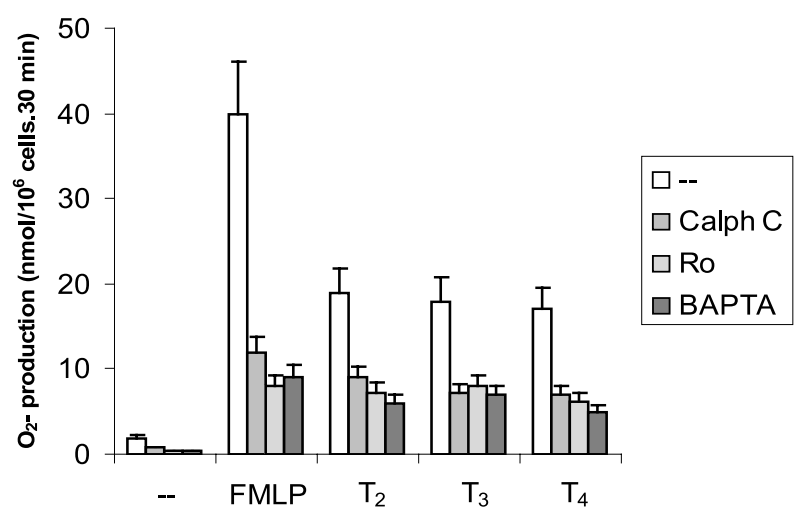

Figure 4 Effects of calphostin C (Calph C) and Ro-32-0432 (Ro), specific inhibitors of PKC, and BAPTA, a calcium chelator, on thyroid hormone $\left(\mathrm{T}_{2}, \mathrm{~T}_{3}\right.$ and $\left.\mathrm{T}_{4}\right)$ - and FMLP-induced $\mathrm{O}_{2}{ }^{-}$ production in human PMNLs. Cells were treated with $50 \mathrm{nM}$ calphostin C or $10 \mathrm{nM}$ Ro-32-0432 and $10^{-5} \mathrm{M}$ BAPTA prior to stimulation with thyroid hormone analogues and FMLP at $10^{-8} \mathrm{M}$. All experiments were performed in triplicate. The inhibitory effects of PKC inhibitors and BAPTA proved to be significant in all cases $(P<0 \cdot 001)$.

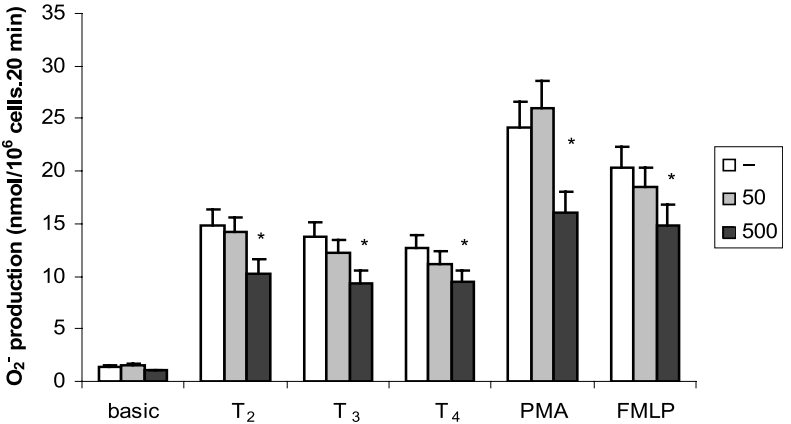

Figure 5 Effect of pre-incubation with PTU, an inhibitor of deiodination, on thyroid hormone $\left(\mathrm{T}_{2}, \mathrm{~T}_{3}\right.$ and $\left.\mathrm{T}_{4}\right)$-, FMLP- and PMA-induced $\mathrm{O}_{2}{ }^{-}$production in human PMNLs. Human PMNLs were pre-incubated with either 50 or $500 \mu \mathrm{M}$ PTU (as shown in the key on the right) for 10 min prior to stimulation with thyroid hormone $\left(10^{-8} \mathrm{M}\right)$, FMLP $\left(10^{-8} \mathrm{M}\right)$ or PMA $\left(10^{-7} \mathrm{M}\right)$. The latter stimulators were used to control the general effect of PTU, if any, on $\mathrm{O}_{2}{ }^{-}$production in PMNLs. Results are expressed as means \pm S.D. from three independent experiments. All experiments were performed in triplicate; ${ }^{*} P<0 \cdot 01$.

stimulation, but the inhibition did not reach the level of significance (Fig. 5). However, at higher concentrations (500-1000 $\mu \mathrm{M})$ PTU significantly inhibited not only thyroid hormone $\left(\mathrm{T}_{4}, \mathrm{~T}_{3}\right.$ and $\left.\mathrm{T}_{2}\right)$ but also FMLP- and PMA-induced $\mathrm{O}_{2}{ }^{-}$production to similar extents (about 30\%; Fig. 5). These results suggest that PTU has a general inhibitory effect on $\mathrm{O}_{2}{ }^{-}$production in PMNLs, as was suggested previously in rat erythrocyte membrane (Faure et al. 1991).

Previously it was demonstrated that thyroid hormone enhanced phagocytosis and the killing of bacteria by granulocytes. The presumed mechanism was the conversion of $T_{4}$ to $T_{3}$ by PMNLs, freeing up iodide to kill micro-organisms (Klebanoff \& Green 1973). Considering our results, that PTU pre-incubation had no specific effect on $\mathrm{T}_{4}$-induced $\mathrm{O}_{2}{ }^{-}$production, we hypothesized that the source of halide for increased killing might be the thyroid hormone-induced halide incorporation into PMNLs. Therefore, the effect of thyroid hormone on ${ }^{125} \mathrm{I}^{-}$incorporation in PMNLs of healthy subjects was determined (Table 1). It was found that both $\mathrm{T}_{3}$ and $\mathrm{T}_{4}$ stimulated ${ }^{125} \mathrm{I}^{-}$incorporation into PMNLs. The effect was more pronounced at a higher concentration $\left(10^{-6} \mathrm{M}\right)$, especially in the case of $\mathrm{T}_{3}$ (Table 1). Considering the facts that myeloperoxidase is a halide-using enzyme, that PMNLs contain it in their cytoplasmic granules and that this enzyme is discarded in the phagosome after stimulation, the effect of thyroid hormone on myeloperoxidase activity was determined. As is shown in Table 1, thyroid hormone $\left(T_{2}, T_{3}\right.$ and $\left.T_{4}\right)$ enhanced myeloperoxidase activity in PMNLs of healthy subjects.

Finally, $\mathrm{O}_{2}{ }^{-}$production in PMNLs of thyroid disease patients after FMLP stimulation was determined. It has to be noted that $\mathrm{O}_{2}{ }^{-}$production in resting PMNLs of 
Table 1 Thyroid hormone $\left(T_{2}, T_{3}\right.$ and $T_{4}$, at either $10^{-6}$ or $10^{-7} \mathrm{M}$ concentration) stimulated ${ }^{125} \mathrm{I}^{-}$incorporation into PMNLs of healthy subjects and resulted in an increase in myeloperoxidase activity

\begin{tabular}{ll}
$\frac{{ }^{125} \mathbf{I}^{-} \text {incorporation }}{(\text { c.p.m.) }}$ \\
\hline $10^{-6} \mathrm{M}$ & $10^{-7} \mathrm{M}$ \\
\hline
\end{tabular}

Thyroid hormone
None
$\mathrm{T}_{2}$
$\mathrm{~T}_{3}$
$\mathrm{~T}_{4}$

$$
\begin{aligned}
& 95350 \pm 11200 \\
& \text { n.d. } \\
& 174800 \pm 25400^{*} \\
& 190400 \pm 41000 \dagger
\end{aligned}
$$

MPO activity ( $\mathrm{nmol} / \mathrm{min}$ per $10^{6}$ cells)

$10^{-7} \mathrm{M}$

$0 \cdot 969 \pm 0 \cdot 122$

$3 \cdot 383 \pm 0 \cdot 922^{*}$

$3 \cdot 473 \pm 0.651^{*}$

$3 \cdot 292 \pm 0 \cdot 926^{*}$

MPO, myeloperoxidase; n.d. not determined.

${ }^{*} P<0 \cdot 02,+P<0 \cdot 008$.

hyperthyroid patients was significantly elevated compared with either controls or hypothyroid patients (Fig. 6). Furthermore, PMNLs of hyperthyroid patients seem to be hyper-reactive to FMLP stimulation (Fig. 6). However, no significant differences were detected in $\mathrm{O}_{2}{ }^{-}$production of resting and FMLP-stimulated PMNLs of hypothyroid patients in comparison with controls. The difference among controls and hyperthyroid patients remained significant when the baseline $\mathrm{O}_{2}{ }^{-}$production was subtracted from the FMLP-stimulated $\mathrm{O}_{2}{ }^{-}$production $(25 \cdot 8 \pm 1 \cdot 7$ versus $35 \cdot 5 \pm 3 \cdot 2 \mathrm{nmol} / 10^{6}$ cells per $20 \mathrm{~min} ; P<0 \cdot 01$ ). Nevertheless, the results of hyperthyroid patients are very similar to the in vitro effect of thyroid hormone preincubation on FMLP-stimulated $\mathrm{O}_{2}{ }^{-}$production (Fig. 2).

\section{Discussion}

In the present study we demonstrated that $\mathrm{T}_{2}, \mathrm{~T}_{3}$ and $\mathrm{T}_{4}$ are able to induce $\mathrm{O}_{2}{ }^{-}$production in human PMNLs in

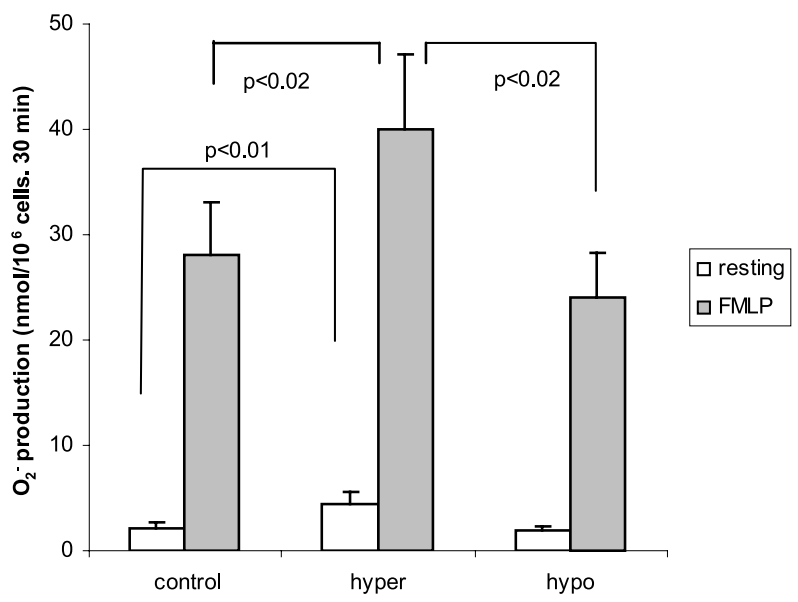

Figure 6 Superoxide anion $\left(\mathrm{O}_{2}{ }^{-}\right)$production in resting and FMLP-stimulated PMNLs of thyroid disease patients compared to healthy controls. Results are expressed as means \pm S.D. in the case of 12 hyperthyroid (hyper), eight hypothyroid (hypo) and 15 healthy controls. All experiments were performed in triplicate. a dose-dependent manner. The time course of this action suggests a novel nongenomic effect of thyroid hormone on the respiratory-burst activity of PMNLs. Several inhibitors of calcium-dependent signalling inhibited thyroid hormone-induced $\mathrm{O}_{2}{ }^{-}$production, including pertussis toxin, the inhibitor of GTP-binding G protein, supporting the existence of a binding site for thyroid hormone on the surface of human PMNLs. Thyroid hormone induced ${ }^{125} \mathrm{I}^{-}$incorporation into PMNLs and resulted in elevated myeloperoxidase activity. After thyroid hormone preincubation, more-pronounced $\mathrm{O}_{2}{ }^{-}$production for FMLP stimulation was observed in healthy PMNLs. Considering the fact that $T_{3}$ and $T_{4}$ concentrations are elevated in hyperthyroid patients, our results might explain the hyper-reactivity of PMNLs in these patients.

Our results concerning the stimulatory activity of thyroid hormone on superoxide anion production in human PMNLs are in good agreement with previous findings. Remarkable increases in the respiratory-burst activity of rat PMNLs, enhanced NADPH oxidase and myeloperoxidase activity were reported after 3 days of $\mathrm{T}_{3}$ treatment (Fernandez \& Videla 1995). The stimulation of reactive oxygen species generation by $\mathrm{T}_{3}$ was demonstrated in euthyroid human subjects as well (Magsino et al. 2000). Others found rapid stimulation of oxygen consumption in human mononuclear blood cells by $\mathrm{T}_{2}$ (Kvetny 1992). Furthermore, $\mathrm{T}_{3}$ treatment of healthy volunteers caused significant increase in the phagocytic capacity and the chemiluminescent activity of PMNLs (Balazs et al. 1980). Some results in hyperthyroid patients also suggest that thyroid hormone might influence oxygen free-radical formation. Enhanced $\mathrm{O}_{2}{ }^{-}$production in PMNLs after FMLP stimulation was observed in hyperthyroid patients (Szabo et al. 1996), and the exacerbation of bronchial asthma in hyperthyroid patients was partially due to the enhanced $\mathrm{O}_{2}{ }^{-}$generation by neutrophils and alveolar macrophages (Kanazawa et al. 1992).

The stimulation of superoxide anion generation in PMNLs by thyroid hormone throws new light on the physiological role of thyroid hormone in the function of white blood cells. Many years ago it was demonstrated that 
thyroid hormone increased the phagocytosis and killing of bacteria by granulocytes. The presumed mechanism was the conversion of $\mathrm{T}_{4}$ to $\mathrm{T}_{3}$ by PMNLs, freeing up iodide to kill micro-organisms (Klebanoff \& Green 1973). Based on our study a new concept about the role of thyroid hormone in cellular defence mechanisms may be outlined: the stimulation of free-radical production and halide (chloride and iodide ions) incorporation into PMNLs. All of these processes play an important role in the host defence mechanism.

Our knowledge about the nongenomic effects of thyroid hormone has increased rapidly over the past few years (Davis \& Davis 1996). The physiologic significance of nongenomic effects was demonstrated on myocardial $\mathrm{Na}^{+}$ channel (Huang et al. 1999), sarcoplasmic reticulum $\mathrm{Ca}^{2+}{ }_{-}$ ATPase activity (Warnick et al. 1993) and the contractile state of vascular smooth muscle cells (Ojamaa et al. 1996). All of these may contribute to the acute effect of thyroid hormone on cardiac output that has recently been described (Walker et al. 1994, 1995, Jamali et al. 1997, Davis \& Davis 2002). The modulation of mitochondrial respiration by thyroid hormone is also well characterized (Lanni et al. 1994, Fernandez \& Videla 1995, Goglia et al. 1999). The list of nongenomic effects is flared by actions on solute transport (Sakaguchi et al. 1996, Huang et al. 1999, Incerpi et al. 1999), regulation of actin polymerization (SiegristKaiser et al. 1990), modulation of $\gamma$-aminobutyric acid (GABA) receptors (Chapell et al. 1998) and stimulation of TSH release from pituitary cells (Roussel et al. 1995). One of the most exciting effects of thyroxine is the potentiation of antiviral effect of interferon $\gamma$ (Lin et al. 1996), which also supports the physiological role of thyroid hormone in the cellular defence mechanisms.

Despite the increasing amount of available data, the molecular mechanism of nongenomic thyroid hormone action is still incompletely understood. The binding site for thyroid hormone on the plasma membrane has not been established. The inconsistent results received in various experimental systems may suggest a number of binding sites for thyroid hormone with various features. The inhibitory effect of pertussis toxin on the thyroid hormone-induced $\mathrm{O}_{2}{ }^{-}$release, as was demonstrated here, supports the existence of a $G$ protein-coupled receptor for thyroid hormone. The activation of mitogen-activated protein kinase pathway by thyroid hormone also assumes the presence of a $G$ protein-coupled receptor (Lin et al.1999a). However, other binding sites are not associated with $\mathrm{G}$ proteins. The effect of $\mathrm{T}_{3}$ on TSH release by rat pituitary cells proved to be pertussis toxin-insensitive (Roussel et al. 1995). The regulation of cytoplasmic pyruvate kinase activity involves a direct interaction of hormone with an enzyme subunit (Ashizawa et al. 1991). Another possible binding site for thyroid hormone might be the plasma membrane $\mathrm{Ca}^{2+}$-ATPase (Davis et al. 1989).

The important role of classical PKC isoenzymes in the mechanism of thyroid hormone-induced superoxide anion generation has been established in the present study. All tested PKC inhibitors blocked the thyroid hormoneinduced $\mathrm{O}_{2}{ }^{-}$release in PMNLs. The most pronounced effect was observed by Ro-32-0432, a specific PKC $\alpha$ and PKC $\beta I$ inhibitor. Our findings are in accordance with previous reports. The possible signal transduction of the nongenomic effect of thyroid hormone was investigated in HeLa cells and the activation of both protein kinase A and PKC was demonstrated (Lin et al. 1999a). Most recently, the involvement of protein tyrosine kinase (PTK) and mitogen-activated protein kinase was published in the potentiation of epidermal growth factor action by thyroxine (Lin et al. 1999b).

Finally, PTU at its therapeutic and 10-fold higher concentrations did not modify differently the superoxid anion generation induced by $\mathrm{T}_{2}, \mathrm{~T}_{3}$ and $\mathrm{T}_{4} . \mathrm{O}_{2}{ }^{-}$ production induced by FMLP and PMA was similarly decreased by the high concentration of PTU. This result excludes the exclusive role of $\mathrm{T}_{2}$ in mediating the stimulation of $\mathrm{O}_{2}{ }^{-}$release in PMNLs and confirms that all the investigated thyroid hormone analogues can bind to the plasma membrane. Previously it was demonstrated that PTU at low concentration $(<100 \mu \mathrm{M})$ inhibits myeloperoxidase activity but does not influence superoxide anion formation in PMA-stimulated neutrophils (Ross et al. 1998), as was demonstrated here. PTU prevented phagocytosis induced by A23187, a calcium ionophore, also by inhibiting myeloperoxidase (Lee et al. 1991) and inhibited PMA-induced chemiluminescence response in PMNLs (Imamura et al. 1986). It was demonstrated that PTU at low concentration prevented lipid peroxidation of erythrocyte plasma membrane (Faure et al. 1991), suggesting an antioxidant capacity of this anti-thyroid drug. However, it must be taken into account that lipid peroxidation is usually induced by hydroxyl radicals. It is possible that PTU in the low concentration range $(<100 \mu \mathrm{M})$ is able to scavenge hydroxyl radical but not superoxide anion. However, at high concentrations $(>500 \mu \mathrm{M})$ it can scavenge superoxide anion as well.

In summary, the present data indicate novel, nongenomic actions of thyroid hormone, the induction of superoxide anion production, incorporation of halides and stimulation of myeloperoxidase activity in human PMNLs. This suggests a new concept for the physiological role of thyroid hormone in cellular defence mechanisms, the stimulation of free-radical production and myeloperoxidase activity. This effect is exerted by $T_{2}, T_{3}$ and $T_{4}$, and mediated by a pertussis toxin-sensitive $\mathrm{G}$ protein and by PKC(s). The model may serve as a tool for further characterization of nongenomic thyroid hormone actions.

\section{Acknowledgements}

This work was supported by a grant from the Hungarian Medical Research Council (ETT 186/2003). The authors 
thank Ms Gyongyi Sallai for her technical assistance. The authors declare that there is no conflict of interest that would prejudice the impartiality of this scientific work.

\section{References}

Ashizawa K, McPhie P, Lin KH \& Cheng SY 1991 An in vitro novel mechanism of regulating the activity of pyruvate kinase $\mathrm{M}_{2}$ by thyroid hormone and fructose 1,6-bisphosphate. Biochemistry 30 7105-7111.

Balazs C, Leovey A, Szabo M \& Bako G 1980 Stimulating effect of triiodothyronine on cell-mediated immunity. European Journal of Clinical Pharmacology 17 19-23.

Boyum A 1968 Isolation of mononuclear cells and granulocytes from human blood. Scandinavian Journal of Clinical and Laboratory Investigation 97 (suppl) 77-89.

Chapell R, Martin J, Machu TK \& Leidenheimer NJ 1998 Direct channel-gating and modulatory effects of triiodothyronine on recombinant $\mathrm{GABA}_{\mathrm{A}}$ receptors. European Journal of Pharmacology 349 $115-121$.

Chen LW \& Jan CR 2001 Mechanism and modulation of formyl-methionyl-leucyl-phenyalanine (fMLP)-induced Ca2+ mobilization in human neutrophils. International Immunopharmacology 1 1341-1349.

Czompa A, Dinya Z, Antus S \& Varga Zs 2000 Synthesis and antioxidant activity of flavonoid derivatives possessing 1,4-benzodioxane moiety. Archiv der Pharmazie 333 175-180.

Davis PJ \& Davis FB 1996 Nongenomic actions of thyroid hormone. Thyroid 6 497-504.

Davis PJ \& Davis FB 2002 Nongenomic actions of thyroid hormone on the heart. Thyroid 12 459-466.

Davis PJ, Davis FB \& Lawrence WD 1989 Thyroid hormone regulation of membrane $\mathrm{Ca} 2(+)$-ATPase activity. Endocrine Research 15 651-682.

Davis PJ, Tillmann HC, Davis FB \& Wehling M 2002 Comparison of the mechanism of nongenomic actions of thyroid hormones and steroid hormones. Journal of Endocrinological Investigation 25 377-388.

Faure M, Lissi EA \& Videla LA 1991 Evaluation of the antioxidant properties of thyroid hormones and propylthiouracil in the brain-homogenate autoxidation system and in the free radical-mediated oxidation of erythrocyte membranes. Chemico Biological Interaction 77 173-185.

Fernandez V \& Videla LA 1995 On the mechanism of thyroid hormone-induced respiratory burst activity in rat polymorphonuclear leukocytes. Free Radical Biology and Medicine 19 359-363.

Goglia F, Moreno M \& Lanni A 1999 Action of thyroid hormones at the cellular level: the mitochondrial target. FEBS Letters $\mathbf{4 5 2}$ $115-120$.

Harvey CB \& Williams GR 2002 Mechanism of thyroid hormone action. Thyroid 12 441-446.

Hennemann G, Docter R, Friesema EC, de Jong M, Krenning EP \& Visser TJ 2001 Plasma membrane transport of thyroid hormones and its role in thyroid hormone metabolism and bioavailability. Endocrine Reviews 22 451-476.

Huang CJ, Geller HM, Green WL \& Craelius W 1999 Acute effects of thyroid hormone analogs on sodium current in neonatal rat myocytes. Journal of Molecular and Cellular Cardiology 31 881-893.

Imamura M, Aoki N, Saito T, Ohno Y, Maruyama Y, Yamaguchi J \& Yamamoto T 1986 Inhibitory effects of antithyroid drugs on oxygen radical formation in human neutrophils. Acta Endocrinology (Copenhagen) 112 210-216.

Incerpi S, Luly P, De-Vito P \& Farias RN 1999 Short-term effects of thyroid hormones on the $\mathrm{Na} / \mathrm{H}$ antiport in L-6 myoblasts: high molecular specificity for 3,3',5-triiodo-L-thyronine. Endocrinology $140683-689$
Jamali IN, Pagel PS, Hettrick DA, Lowe D, Kersten JR, Tessmer JP \& Warltier DC 1997 Positive inotropic and lusitropic effects of triiodothyronine in conscious dogs with pacing-induced cardiomyopathy. Anesthesiology 87 102-109.

Kanazawa H, Kurihara N, Hirata K, Terakawa K, Fijuwara H, Matsushita H, Ota K \& Takeda T 1992 The effect of thyroid hormones on the generation of free radicals by neutrophils and alveolar macrophages. Aerugi 41 135-139.

Klebanoff SJ \& Green WL 1973 Degradation of thyroid hormones by phagocytosing human leukocytes. Journal of Clinical Investigation $\mathbf{5 2}$ 60-72.

Kvetny J 1992 3,5-T2 stimulates oxygen consumption, but not glucose uptake in human mononuclear blood cells. Hormone and Metabolic Research 24 322-325.

Lanni A, Moreno M, Lombardi A \& Goglia F 1994 Rapid stimulation in vitro of rat liver cytochrome oxidase activity by 3,5-diiodo-L-thyronine and 3,3+-diiodo-L-thyronine. Molecular and Cellular Endocrinology 99 89-94.

Lee E, Fujita M \& Kariya K 1991 Stimulation of phagocytosis in rat polymorphonuclear leukocytes by A23187 is accompanied by activation of myeloperoxidase. Biochemical and Biophysical Research Communications 176 364-370.

Lin HY, Thacore HR, Davis FB \& Davis PJ 1996 Potentiation by thyroxine of interferon- $\gamma$-induced antiviral state requires PKA and PKC activities. American Journal of Physiology - Cell Physiology 271 C1256-C1261.

Lin HY, Davis FB, Gordinier JK, Martino LJ \& Davis PJ 1999a Thyroid hormone induces activation of mitogen-activated protein kinase in cultured cells. American Journal of Physiology - Cell Physiology 276 C1014-C1024.

Lin HY, Shih A, Davis FB \& Davis PJ 19996 Thyroid hormone promotes the phosphorylation of STAT3 and potentiates the action of epidermal growth factor in cultured cells. Biochemical Journal 338 427-432.

Magsino Jr CH, Hamouda W, Ghanim H, Browne R, Aljada A \& Dandona P 2000 Effect of triiodothyronine on reactive oxygen species generation by leukocytes, indices of oxidative damage, and antioxidant reserve. Metabolism 49 799-803.

Mohacsi A, Kozlovszky B, Kiss I, Seres I \& Fülöp T 1996 Neutrophils obtained from obliterative atherosclerotic patients exhibit enhanced resting respiratory burst and increased degranulation in response to various stimuli. Biochimica et Biophysica Acta 1306 210-216.

Ojamaa K, Klemperer JD \& Klein I 1996 Acute effects of thyroid hormone on vascular smooth muscle. Thyroid 6 505-512.

Ribeiro RC, Apriletti JW, Wagner RL, West BL, Feng W, Huber R, Kushner PJ, Nilsson S, Scanlan T, Fletterick RJ et al. 1998 Mechanism of thyroid hormone action: insight from X-ray crystallographic and functional studies. Recent Progress in Hormone Research 53 351-392.

Ross DA, Dey I, Janes N \& Israel Y 1998 Effect of antithyroid drugs on hydroxyl radical formation and $\alpha-1$-proteinase inhibitor inactivation by neutrophils: therapeutic implications. Pharmacology and Experimental Therapentics 285 1233-1238.

Roussel J-P, Grazzini E, Zumbihl R, Rodrigez E \& Astier H 1995 Triiodo-L-thyronine enhances TRH-induced TSH release from perfused rat pituitaries and intracellular $\mathrm{Ca}^{2+}$ levels from dispersed pituitary cells. European Journal of Pharmacology 289 205-215.

Sakaguchi Y, Cui G \& Sen L 1996 Acute effects of thyroid hormone on inward rectifier potassium channel currents in guinea pig ventricular myocytes. Endocrinology 137 4744-4751.

Segal J 1990 In vivo effect of 3,5,3'-triiodothyronine on calcium uptake in several tissues in the rat: evidence for a physiological role for calcium as the first messenger for the prompt action of thyroid hormone at the level of the plasma membrane. Endocrinology 127 $17-24$.

Siegrist-Kaiser CA, Juge-Aubry C, Tranter MP, Ekenbarger DM \& Leonard JL 1990 Thyroxine-dependent modulation of actine 
polymerization in cultured astrocytes. A novel, extranuclear action of thyroid hormone. Journal of Biological Chemistry 265 5296-5306.

Sundquist J, Blas SD, Hogan JE, Davis FB \& Davis PJ 1992 The alpha 1 -adrenergic receptor in human erythrocyte membranes mediates interaction in vitro of epinephrin and thyroid hormone at the membrane Ca (2+)-ATPase. Cellular Signalling 4 795-799.

Szabo J, Foris G, Mezosi E, Nagy EV, Paragh G, Sztojka I \& Leovey A 1996 Parameters of respiratory burst and arachidonic acid metabolism in polymorphonuclear granulocytes from patients with various thyroid diseases. Experimental and Clinical Endocrinology and Diabetes 104 172-176.

Tapia G, Fernandez V, Varela P, Corneiro P, Guerrero J, \& Videl LA 2003 Thyroid hormone-induced oxidative stress triggers nuclear factor- $\mathrm{\kappa B}$ activation and cytokine gene expression in rat liver. Free Radical Biology and Medicine 35 257-265.

Videla LA, Correa L, Rivera M \& Sir T 1993 Zymosan-induced luminol-amplified chemiluminescence of whole blood phagocytes in experimental and human hyperthyroidism. Free Radical Biology and Medicine 14 669-675.

Walker JD, Crawford FA, Mukherjee R, Zile MR \& Spinale FG 1994 Direct effects of acute administration of 3,5,3' triiodo-L-thyronine on myocyte function. The Annals of Thoracic Surgery $\mathbf{5 8} 851-856$.

Walker JD, Crawford FA, Mukherjee R \& Spinale FG 1995 The direct effects of 3,5,3'-triiodo-L-thyronine (T3) on myocyte contractile processes. Insights into mechanisms of action. Journal of Thoracic and Cardiovascular Surgery 110 1369-1379.

Warnick PR, Davis PJ, Davis FB, Cody V, Galindo Jr J \& Blas SD 1993 Rabbit skeletal muscle sarcoplasmic reticulum $\mathrm{Ca}(2+)$-ATPase activity: stimulation in vitro by thyroid hormone analogues and bipyridines. Biochimica at Biophysica Acta 1153 184-190.

Received 28 December 2004

Accepted 25 January 2005 